should be replaced by a concept of relative stability in a dynamic environment.

The information presented in this paper should add to an understanding of environmental dynamics in such circumstances, in addition to furthering an understanding of the impact of possible future conservation or use of some beach environments, at least in Scotland. The direct impact of tourism on ecosystems can be measured (Liddle \& Greig-Smith, 1975a, 1975b). What is presented here is an environmental framework into which pertinent impact statements can be placed, recognising the fact also that such impacts will alter the dynamics of the system itself.

\section{SUMMARY}

The machair coastal areas of the Outer Hebrides form one of the more distinctive coastal environments in Britain and owe their origin to an apparently unique, as yet not clearly understood, combination of factors which operated in the late postglacial period. A further distinguishing characteristic is the often quite extensive level machair grassland plain, which is suggested here as being the last of a series of evolutionary phases which took place from the time of initial sand deposition ( $c a 6000$ B.P.) until $c a 2000$ B.P. There is evidence that, in a modified form, these processes may have continued right through to the present time.

Interrelationships between present-day vegetation communities, minor landform features, relative position of these 'biotopographic' units, and evidence of formerbut now buried-organic soil horizons, enables a theory for the formation of these machair plains to be put forward. The most complete set of data upon which this theory is based is available at Grogarry Machair, South Uist. Although precise dating of organic horizons is difficult, a time-sequence is made possible by reference to datable archaeological evidence from this and other areas in the Outer Hebrides. Further application of this proposed model in other areas at least of the Hebrides, together with ${ }^{14} \mathrm{C}$ dating and related cultural evidence from these areas, would test the value and relevance of this proposal. The significance of such an approach to resource management problems provides a broader context for this issue.

\section{REFERENCES}

BUTLER, B. E. (1959). Periodic Phenomena in Landscapes as a Basis for Soil Studies. Soils Publ. No. 14, CSIRO, Melbourne, Australia: $20 \mathrm{pp}$.

CONSERVATION FOUNDATION (1976). Barrier Islands and Beaches. Technical Proc. of the 1976 Barrier Island Workshop, Annapolis, Maryland, May 1976. Conservation Foundation, Washington, D.C.: 149 pp., illustr.

DICKINSON, G. (1968). The Vegetation of Grogarry Machair, South Uist. Unpublished report, Nature Conservancy, Edinburgh, U.K.: 45 pp., illustr.

DICKINSON, G. (1974). A Geographic Study of Machair in the Uists. Unpublished Ph.D. thesis, University of Glasgow, Glasgow, U.K.: Vol. 1, 240 pp., illustr., Vol. 2, 99 pp., illustr.

EVANS, J. G. (1971). Habitat changes on the calcareous soils of Britain: the impact of Neolithic Man. Pp. 27-73 in Economy and Settlement in the Neolithic and Early Bronze Age in Britain and Europe (Ed. D. D. A. Simpson). Leicester University Press, Leicester, U.K.: 186 pp.

GODFREY, P. J. \& GODFREY, M. M. (1973). Comparisons of ecological and geomorphic interactions between altered and unaltered barrier island systems in North Carolina. Pp. 239-58 in Coastal Geomorphology (Ed. D. R. Coates). Proc. Third Annu. Geomorphology Symp., Publications in Geomorphology, State University of New York, Binghamton, N.Y.: 404 pp., illustr.

LETHBRIDGE, T. C. (1952). Excavations at Kilpheder. Proc. Prehistoric Soc., 18, pp. 176-93.

LIDDLE, M. J. \& GREIG-SMITH, P. (1975a). A survey of tracks and paths in a sand-dune ecosystem: I, Soils. J. Appl. Ecol., 12, pp. 893-908.

LIDDLE, M. J \& GREIG-SMITH, P. (1975b). A survey of tracks and paths in a sand-dune ecosystem: II, Vegetation. J. Appl. Ecol., 12, pp. 909-30.

McARTHUR, J. L. (1971). Periodicity in upland morphogenesis. Pp. 186-91 in Sixth New Zealand Geo. Conf., Christchurch, New Zealand. New Zealand Geographical Society, Christchurch, New Zealand: 288 pp.

RANDALL, R. E. (1973). Calcium carbonate in dune soils: Evidence for geomorphic change. Area, 5 (4), pp. 308-10.

RITCHIE, W. (1966). The Physiography of the Machair of South Uist. Unpublished Ph.D. thesis, University of Glasgow, Glasgow, U.K.: Vol. 1, 234 pp., illustr., Vol. 2, 190 pp., illustr.

RITCHIE, W. (1967). The machair of South Uist. Scot. Geog. Mag., 83, pp. 161-173.

RITCHIE, W. \& MATHER, A.S. (1971). Conservation and use: case-study of beaches of Sutherland, Scotland. Biol. Conserv., 3 (3), pp. 199-207, 4 figs.

ROBERTS, H. W., KERR, D. H. \& SEATON, D. (1959). The machair grasslands of the Hebrides. J. Br. Grassland Soc., 14, pp. 223-8.

\title{
Parks Canada Issues New Policy
}

Protecting Canada's Heritage, both natural and cultural, has become the central theme of Parks Canada's new policy. Recognizing the need to update and revise an earlier policy dating from 1964, Parks Canada undertook a major consultation process involving other federal departments, provincial governments, and more than 300 individuals and non-governmental organizations. The consultation revealed deep-seated support for the protection of Canada's Heritage, and widespread public appreciation of its value to all Canadians.

The policy document, entitled 'Parks Canada Policy' (69 pp., illustr., 1979) provides guidance for the Govern- ment as well as the public service in ensuring that the protection of historic, cultural, and natural, resources receives a number-one priority in the allocation of manpower and financial resources.

The policy document* is available in English or French at no charge from Parks Canada, Les Terrasses de la Chaudière, Ottawa, Ontario K1A OH4, Canada.

Harold K. Eidsvik, Executive Officer Commission on National Parks and Protected Areas I.U.C.N., Avenue du Mont Blanc 1196 Gland

Switzerland. 